\section{Cultivation of Bulbs}

DuRING recent years, bulbs have become a field crop of considerable importance, especially in the Scilly Isles, Cornwall, and Lincolnshire, and growers, or intending growers, will welcome the illustrated bulletin No. 44, entitled "Narcissi Culture ", recently issued by the Ministry of Agriculture (H.M. Stationery Office, $9 d$.). Although bulbs grow well on a number of soils, good drainage and cultivation are essential, but the direct application of fresh manure should be avoided. Potatoes which have been adequately manured leave the soil in excellent condition for bulbs. Among some of the more important questions upon which advice is given are those relating to grading, lifting, storage, and planting. Eelworm has become a serious menace to the bulb-grower, and sterilisation by means of hot water (three hours' immersion at $110^{\circ} \mathrm{F}$.) is strongly advocated, the treatment being given when the bulbs are in as dormant a condition as possible, or injury may result. As regards flowers, while good grading, bunching, and packing are essential, the importance of making the flowers look attractive by means of details such as packing-paper should not be overlooked. Although this trade in narcissus flowers has increased so enormously, the allied bulbgrowing industry could become one of even greater financial importance, for the sum spent annually on imported bulbs amounts to nearly $£ 1,500,000$.

\section{Manures and Manuring}

IT is recognised that owing to the variation in local conditions, it is impossible to give a complete guide to manuring on every farm. Still, the information supplied in Bulletin No. 36, entitled "Manures and Manuring ", which has recently been issued by the Ministry of Agriculture to replace the sectional volume of Leaflets No. 8 on the same subject, the text having been considerably revised by Mr. H. V. Garner (H.M. Stationery Office, price 1s. 3d. net), should be of the utmost value to farmers, if they are to derive the fullest benefit from the money spent on fertilisers. The Bulletin is divided into three parts, the first of which deals with organic manures. In spite of the recent great development in artificial fertilisers, farmyard manure is still the stand-by of arable farmers, but although it is by far the most important type of organic manure, the value of other materials such as liquid manure, town refuse, poultry manure, and seaweed is evidently considerable. Part ii. is devoted to artificial fertilisers. The various types of nitrogenous, phosphatic, and potash manures now on the market are described, while a further section deals with the use of compound manures. The third part supplies useful information with regard to the purchase and use of artificial fertilisers, and enables the farmer to determine the comparative value and costs of nitrogen, phosphoric acid, and potash in the different forms without difficulty. Some suggestions are made, on quite general lines, as to the treatment of farm crops, and a further section is devoted to a discussion of soil analysis and its bearing on cropping and manuring.

No. 3257, VoL. 129]

\section{Improvements in Epidiascopes}

RECENT developments in the design of instruments for the projection of opaque objects have been directed towards increasing the intensity of light directed on the object, improving the quality of the projection lens, and simplifying the mechanical construction in order to ensure lightness, durability, and ease of manipulation. An active part in the development and perfecting of such instruments has been taken by Messrs. Newton and Co. of 72 Wigmore Street, London, W.1. Since the production of their first episcope in 1916, the efficiency and convenience of succeeding models have increased with each stage of development. The high efficiency of their latest types is due largely to the use of special diffusion reflectors. The illuminant is a single 500-watt gasfilled lamp which is so placed that four of these reflectors can be used to concentrate the light on the object and give a uniform illumination over the whole field, an area 6 in. $\times 6$ in. This arrangement, combined with a large aperture projection lens, provides an illumination on the screen equal to that obtained from earlier instruments employing two lamps. As only one lamp is used and the lamp-house well ventilated, the objects are not exposed to any great heat. When it is necessary to keep them at room temperature a ventilating fan can easily be fitted. The silver-surfaced reversing mirror is mounted outside the lamp-house and, consequently, is not subjected to heating from the lamp. The construction of the body, which is of cast aluminium, is such as to ensure lightness and durability; and the design of the instrument renders its operation extremely simple. Precise and easy adjustments are provided for all necessary movements. Instruments of different sizes, embodying these improvements, are available with working distances ranging from $16 \mathrm{ft}$. to $40 \mathrm{ft}$.

\section{Electrical Conveyors in Mines}

IT is generally admitted that the only real way to increase the prosperity of a coal mine is to increase the output per head of the workers employed. Of recent years great improvements have been made in the methods of the removal of the coal broken at the working face by mechanical conveyors actuated by electric motors. The Metropolitan-Vickers Electrical Company has specialised in the production of motors and control gear for this purpose. In the December issue of the firm's Gazette, an account is given of the many rigorous conditions these motors have to satisfy and the various types of conveyor used in practice. In the belt conveyor the coal is carried on a moving continuous belt. In the shaker conveyor it is conveyed by an oscillating trough, which moves slowly in one direction but has a comparatively quick return. The coal is thus carried forward in the desired direction by a series of jerks. In the scraper conveyor the coal is conveyed by a continuous scraper working in a fixed trough. For each type of conveyor the demands on the electrical motor are different and so also are the arrangements of the electrical control equipment. Graphs are given, showing how the loads on these types 
of conveyor vary with the time. In the motors ordinarily used, causes of failure arise from the whipping of the shaft and from the ingress of stone dust at the bearings. In the motors described, the roller-bearing at the driving end and the ball-bearing at the opposite end are both constructed in dust-proof 'housings'. The diameter of the shaft of a Metropolitan-Vickers new 15-h.p. conveyor motor is 2.5 in. and the rotating part is practically indestructible. The progress made in mechanical haulage will greatly diminish the use of animals underground for haulage purposes.

\section{British High-Speed Aircraft}

ThE Aeronautical Research Committee has recently issued a résumé of the original scientific work done by various authorities in Great Britain upon the development of racing seaplanes, which has led finally to the winning outright of the Schneider Trophy and the breaking of the world's speed record during September 1931 (Reports and Memoranda, No. 1300. "Collected Reports on British High Speed Aircraft for the 1927 Schneider Trophy Contest", by W. L. Cowley. London: H.M. Stationery Office). This is a departure from the normal procedure of issuing information in disconnected reports and memoranda as it becomes available, which has the advantage that it becomes virtually a textbook upon its subject and saves the labour necessary in hunting up such information when issued in separate pamphlets. On the other hand, if it is necessary to wait for more than four years for the collection and collation of such information, the advantage of its more convenient method of issue is largely outweighed by the obsolescence of its material. The subject matter is divided into separate headings of research, specifications, design and construction, inspection and test, and operational. It deals in great detail with three machines that are widely different in characteristics regarded from the point of view of high speed flight. The monoplane versus biplane, and the air-cooled versus water-cooled engine controversy is thoroughly fought out with representative machines of each class. The most significant thing about the report is the agreement between scientific prediction and actual results, and the ability of scientific investigation to explain apparent phenomena arising during practical use of the aircraft.

\section{Nickel in Marine Engineering}

THE January issue of the Transactions of the Institute of Marine Engineers contains, as usual, a selection of important articles from the technical press, and a report of a paper on "Nickel and Nickel Alloys in Marine Engineering", read to the Institute by Mr. J. McNeil on Dec. 8. Of all the many uses to which nickel has been put aboard ship, none has proved more valuable than when alloyed with copper for condenser tubes. For a very long period, the deterioration of brass condenser tubes, with its accompanying trouble through leakage of sea water, has been a very serious problem, especially in ships fitted with water-tube boilers, but it appears to have been solved at last by the use of an alloy of 70 per cent copper and 30 per cent nickel for the tubes. Alloyed with both ferrous or non-ferrous metals, nickel is used for steam turbine blades and nozzles, high-pressure steam valves and fittings, propellers, pistons and liners of Diesel engines, reduction gear wheels, and even crankshafts. Recently a process has been evolved in which nickel can be deposited in thick layers and thus worn parts built up. There is remarkable adhesion between steel and deposited nickel, and the resistance to shear of a thick ring of nickel deposited on steel is stated to be practically that of the metal itself.

\section{Arctic Exploration}

MUCH activity in polar exploration during the last year, particularly in Greenland and Northern Land and adjacent islands, is noted in the Polar Record for January. When Nansen crossed Greenland in 1888, the journey was considered to be difficult and adventurous. Since that date several other crossings have been made, but no period has been so fruitful in the exploration of the ice sheet as 1930 and 1931 . During that time, two observatories have been instituted and used for longer or shorter periods on the ice, including the German station of the Wegener expedition in the centre; three new crossings of the ice-sheet have been made, including one across the greatest width; and for the first time, echo measurements of the thickness of the ice have been taken. It is also noted that Soviet explorers from the station on the Kamenev Islands to the west of Northern Land, in long sledge journeys, have filled in the western coasts of that land and determined its northern extremity in lat. $83^{\circ} 16^{\prime} \mathrm{N}$., long. $95^{\circ} 37^{\prime} \mathrm{E}$., thus finishing the last piece of pioneer work that the arctic regions offered. Details of these and various other polar explorations are given in the journal.

\section{The Malabar District of India}

A series of articles on the Malabar district of India is published in an enlarged number of the Journal of the Madras Geographical Association (Oct. 1931-Jan. 1932). These papers were read at a conference of the Association held at Palghat in May 1931. They cover the geology, meteorology, botany, and agriculture of the district, and are illustrated by various maps. Following these there are other papers dealing with modern and ancient trade, trade routes, and urban centres. A particularly interesting paper treats of Roman trade centres on the Malabar coast. There are also notes on the place names. The volume is a useful contribution to the study of India, and is chiefly the work of Indian teachers.

\section{Tours in the U.S.S.R.}

IN 1931 the Society for Cultural Relations arranged two conducted tours to demonstrate present activities in science and medicine in the U.S.S.R. Similar tours, each lasting about a month, are being organised this year between July 15 and Sept. 15. It is hoped to arrange parties for physicists, biologists, medical men, and others, each party being limited to about twenty persons. Travelling arrangements will be made by Intourist, Ltd., Bush House, Aldwych, W.C.2, and

$$
\text { No. } 3257 \text {, VoL. 129] }
$$

